\title{
Serum and follicular fluid thyroid hormone levels and assisted reproductive technology outcomes
}

\author{
Yun Ying Cai ${ }^{1,2}$, Na Lin ${ }^{3}$, Lan Ping Zhong ${ }^{3}$, Hui Juan Duan ${ }^{2}$, Yun Hua Dong ${ }^{3}, Z_{e} \mathrm{Wu}^{3^{*}}$ and Heng Su ${ }^{1,2^{*}}$ (D)
}

\begin{abstract}
Objective: The objective ofthis study was to assess the association between thyroid hormone (TH) levels in follicular fluid (FF) and serum and to determine whether THs impact assisted reproductive technology (ART) outcomes.
\end{abstract}

Methods: This study enrolled 299 women undergoing ART. Blood samples were drawn on the day of human chorionic gonadotrophin (HCG) administrationand analysed for thyroid-stimulating hormone (TSH), thyroxine(T4), triiodothyronine(T3), free T4 (fT4), free T3(fT3), thyroid peroxidase antibody (TPOAb) and thyroglobulin antibody (TGAb) levels. FF was obtained on the oocyte pick up (OPU) day and analysed forTSH, T4, T3, fT4, fT3, TPOAb, TgAb and estradiol levels.

Results: (1) There were significant positive correlations between serum and FF TH and thyroid autoantibody levels. Statistically significant differences were discovered in serum and FF levels of TSH ( $p \leq 0.001)$, T4 ( $p \leq 0.001)$, T3 ( $p \leq$ $0.001)$, TPOAbs $(p \leq 0.001)$ and TGAbs $(p=0.021)$.

(2) Serum T4 levels $[121.9(104.8,140.8)$ vs $114.1(98.6,130.6) \mathrm{nmol} / \mathrm{l}, p=0.026]$, serum fT4 levels[(19.0(17.7,21.8) vs 18.6(17.0,20.1) $\mathrm{pmol} / \mathrm{l}, p=0.026]$, serum T4/T3 ratios $[62.5(55.7,66.2)$ vs $59.4(53.4,64.9), p=0.029]$, FF fT4 levels $[19.0(17.5,21.3)$ vs $18.1(16.8,19.9) \mathrm{pmol} / \mathrm{l}, p=0.009]$ and FF T4/T3 ratios $[52.6(46.4,57.3)$ vs $50.0(43.7,53.1), p=0.004]$ were significantly higher in the successful pregnancy group than the implantation failure group.

(3) Spearman's rank correlation analysis revealed positive associations of both the FF T4/T3 ratio and serum TSH levels with the numbers of retrieved oocytes (total or MII) and embryos (fertilized, cleavage, and good quality).

Conclusions: TH levels in FF are strongly correlated with those in serum on the HCG day, and THs on the HCG day may affect ART outcomes.

Keywords: Thyroid hormones, Follicular fluid, Controlled ovarian hyperstimulation, Thyroid autoimmunity

\section{Introduction}

Thyroid hormones (THs) are related to infertility and multiple adverse neonatal and maternal consequences $[1,2]$. Recently, many studies have evaluated the relationship between ART outcomes and thyroid function [3-5]. A growing body of literature debates what constitutes "normal" gestational and preconceptional thyroid

\footnotetext{
* Correspondence: wuzes2010@163.com; su_hen@hotmail.com

${ }^{3}$ Reproductive Medicine Center, The Affiliated Hospital of Kunming University of Science and Technology, Kunming 650500, Yunnan Province, People's Republic of China

'Medical School, Kunming University of Science and Technology, Kunming 650500, Yunnan Province, China

Full list of author information is available at the end of the article
}

function and treatment cut-offs $[4,5]$. The latest metaanalysis on preconception subclinical hypothyroidism ( $\mathrm{SCH}$ ), which included 14,846 participants, found no significant differences in ART-related outcomes between different thyroid-stimulating hormone (TSH) level groups when the TSH cut-off was set to $2.5 \mathrm{mIU} / \mathrm{L}$. However, when a broader TSH cut-off range (3.5-5 mIU/L) was used, the miscarriage rate was higher in the preconception $\mathrm{SCH}$ group than in the normal group [4]. On the other hand, several studies of euthyroid infertile women undergoing intrauterine insemination (IUI) [6-8], found no differences in TSH levels among different IUI outcome groups. In addition, most previous studies categorized women with no

(C) The Author(s). 2019 Open Access This article is distributed under the terms of the Creative Commons Attribution 4.0 International License (http://creativecommons.org/licenses/by/4.0/), which permits unrestricted use, distribution, and 
history of thyroid disease and normal TSH levels as euthyroid; TH levels and thyroid antibody status were not known.

Follicular fluid (FF) supports the acquisition of development competence in oocytes $[9,10]$, and provides the important microenvironment for oocyte maturation. Changes in the FF levels of hormonesand metabolites have been reported to influence oocyte quality, early embryo development, and subsequent pregnancy [11, 12]. Since biological effects of THs are regulated by deiodinase (DIO) in peripheral tissue [13, 14], serum TH levels do not always predict tissue-specific effects in target organs, and local THs may play a direct role in physiological functions. Although the presence of THs in human FF was verified in 1993 [15], the concentration of THs in FF has been analysed in only a small number of studies $[16,17]$. One preliminary observational study found that fT4 in FF were higher in infertile patients than in the healthy population [18]. However, data from literature are not sufficiently clear to definitely state the relationship between serum and FF TH levels and the outcomes of assisted reproductive technology (ART),such as in vitro fertilisation (IVF).

Previous studies used only serum TSH as a biomarker to evaluate thyroid function. The aim of our study was to compare the relationship of serum and FFTHs withcycle parameters and ART outcomes...

\section{Materials and methods}

This study was approved by the Ethics Committee of the First People's Hospital of Yunnan Province and was carried out according to good clinical practices. Informed consent was obtained from each patient.

\section{Patients and sample collection}

This prospective study involved a cohort of subfertile women who underwent one IVF or IVF-intracytoplasmic sperm injection (ICSI) cycle. For this study, two hundred and ninety-nine subfertile women were enrolled. A total of 165 FFsamples were collected for the final analysis. TSH levels were determined at the first visitto our clinical center. Only patients with normal TSH and a baseline Day $3 \mathrm{FSH}$ level $<10 \mathrm{IU} / \mathrm{L}$ were included in the study. We excluded women with pre-exiting thyroid disease or medication usage $(N=30)$ and those withcancelled cycles $(N=104))$. Participants were followed to determine early pregnancy outcomes (3 months). This analysis exclusively refers to the first treatment cycle.

\section{IVF procedure and sample collection}

For controlled ovarian stimulation (COS), we used one of two protocols, treatment with the long gonadotropinreleasing hormone agonist triptorelin (Decapeptyl $1.25 \mathrm{mg}$, Ferring Co, Kiel, Germany) for 2 weeks, starting on cycle day 21 or the antagonist protocol (Cetrotide $0.25 \mathrm{mg} / \mathrm{ml}$, cetrorelix acetate, Merck Serono, Frankfurt, Germany) in combination with recombinant FSH (Gonal F Serono, Aubonne, Switzerland). Human chorionic gonadotrophin(HCG) $(250 \mu \mathrm{g}$ of Gonal f,EMD Serono, Aubonne, Switzerland) was administered when more than three follicles reached a diameter of $>18 \mathrm{~mm}$. Oocyte retrieval was performed by the transvaginal ultrasound-guided approach, $36 \mathrm{~h}$ after HCG injection. Blood samples were drawn in the morning on the day of HCG administration. $\mathrm{FF}$ was collected only from the first puncture of oneovary. Samples were processed and stored at $-20^{\circ} \mathrm{C}$ until analysis. Based on availabe literature and data, we selected the total number of blastomeres andMII oocytes as potential determinants of oocyte maturation. Clinical pregnancy was defined as ultrasonographic demonstration of a vital embryo within an intrauterine gestational sack 4-5 weeks after embryo transfer. The implantation rate was calculated as the ratio of the number of gestational sacks identified at this time to the number of embryos transferred.

\section{Laboratory analysis}

The levels of TSH, triiodothyronine (T3), T4, free T3(fT3), free $\mathrm{T} 4(\mathrm{fT} 4)$, thyroid peroxidase antibody (TPOAb) and thyroglobulin antibody (TGAb) were measured with electro-chemiluminescence (ECL) immunoassays (CobasElesys 601, Roche). The assays had the following reference ranges and intra-assay coefficients of variation $(\mathrm{CVs})$ : $\mathrm{TSH}$, $0.27-4.2 \mathrm{mIU} / \mathrm{l}$ and $1.57-4.82 \%$; $3,1.3-3.1 \mathrm{nmol} / \mathrm{l}$ and 1.71-5.97\%; T4, 66-181 nmol/l and 2.36-6.12\%; fT3, 3.1$6.8 \mathrm{pmol} / \mathrm{l}$ and $2.42-5.61 \%$; fT4, $12-22 \mathrm{pmol} / \mathrm{l}$ and $2.24-$ 6.34\%; TPOAb $\leq 34 \mathrm{IU} / \mathrm{ml}$ and $1.98-6.7 \%$; and $\mathrm{TGAb}$, $\leq 115 \mathrm{IU} / \mathrm{ml}$ and $1.64-5.37 \%$.

\section{Statistical analysis}

Quantitative values are expressed as the mean \pm SD or as the median and interquartile range, as appropriate. Student's t-test was used to analyse continuous data with a normal distribution. Wilcoxon Rank-Sum test (nonparametric analysis) was used to evaluate continuous data without a normal distribution; chi-square analysis was used for categorical data with large cell counts, and Fisher'sexact test was used to evaluate categorical data with small cell counts.A $p$-value $\leq 0.05$ was considered statistically significant.

\section{Results}

Relationship and difference between serum and follicular fluid thyroid hormones

Our results showed significant positive correlation between serum THlevels and FF TH levels (TSH: $r=0.876, p \leq$ 0.001;T4: $r=0.788, p \leq 0.001$; T3: $r=0.727, p \leq 0.001$;T4: $r=0.853, p \leq 0.001$; fT3: $r=0.702, p \leq 0.001$ ). Significant differences in TSH $(2.22 \pm 1.13 \mathrm{vs} 2.73 \pm 1.43 \mathrm{mIU} / \mathrm{l}, p \leq 0.001)$, $\mathrm{T} 4(118.57 \pm 22.6 \mathrm{vs} 105.85 \pm 21.5 \mathrm{nmol} / \mathrm{l}, \quad p \leq 0.001)$ and 
T3 levels $(1.97 \pm 0.33 \mathrm{vs} 2.10 \pm 0.32 \mathrm{nmol} / \mathrm{l}, p \leq 0.001)$ were found between serum and FF. Moreover,fT4 and fT3 followed the same trend, but the differences did not reach statistical significance.

\section{Relationship and difference between serum and follicular fluid thyroid autoantibodies}

Our results showed a significant correlation between serum and FF TPOAbs $(r=0.808, p \leq 0.001)$ and TGAbs $(r=0.601$, $p \leq 0.001$ ).

TPOAb $[15.27(8.94,19.9)$ vs $9.37(5,12.7) \mathrm{IU} / \mathrm{ml}, p \leq$ $0.001]$ and TGAb levels $[17.6(14.8,20.5)$ vs $15.6(13.7$, 20.3), $p=0.021$ ] were higher in serum than in FF.

No statistically significant differences in serum TSH ( $2.53 \pm 1.03$ vs $2.22 \pm 1.15 \mathrm{mIU} / \mathrm{ml}, p=0.762)$, T4(116.2 \pm 10.63 vs $118.81 \pm 23.48 \mathrm{nmol} / \mathrm{l}, \quad p=0.941), \mathrm{T} 3(1.93 \pm 0.12-$ vs $1.98 \pm 0.34 \mathrm{nmol} / \mathrm{l}, p=0.461)$, fT4 $(19.55 \pm 2.7$ vs $19.16 \pm$ $3.11 \mathrm{pmol} / \mathrm{l}, p=0.169)$ and fT3 levels $(4.68 \pm 0.32$ vs $4.55 \pm$ $0.73 \mathrm{pmol} / \mathrm{l}, p=0.154$ ) were found between patients with and without thyroid autoantibodies.

\section{Serum and follicular fluid parameters andART characteristics and outcomes}

We observedslightly higher serum T4 levels [121.9(104.8, 140.8) vs $114.1(98.6,130.6) \mathrm{nmol} / \mathrm{l}, p=0.026]$, serum fT4 levels[(19.0(17.7,21.8) vs 18.6(17.0,20.1) $\mathrm{pmol} / \mathrm{l}, p=0.026]$, serum T4/T3 ratios $[62.5(55.7,66.2)$ vs $59.4(53.4,64.9)$, $p=0.029]$, FF fT4 levels $[19.0(17.5,21.3)$ vs $18.1(16.8,19.9)$ $\mathrm{pmol} / \mathrm{l}, p=0.009]$ and FF T4/T3 ratios $[52.6(46.4,57.3) \mathrm{vs}$ $50.0(43.7,53.1), p=0.004$ ] in women with a successful pregnancy than in women with implantation failure in the respective treatment cycle. In terms ofTSH,T3, fT3, TPOAbs andTGAbs in serum and FF, there were no significant differences between the two groups (Table 1).

Spearman's rank correlation analysis showed positive associations of both the FF T4/T3 ratio and serum TSH levels withthe number of retrieved oocytes (total or MII) and the number of embryos (fertilized, cleavage, and good quality). These associations were slightly stronger for serum TSH than for FF T4/T3 (Table 2). On the other hand, the positive correlations observed between TSH and the number of good quality oocytes were stronger for serum than for FF (serum TSH $r=0.41, p \leq 0.001$; FF TSH $r=0.31, p \leq 0.001$ ).

No statistically significant correlation wasfound between the number of retrieved oocytes or fertilized oocytes and the levels of thyroid autoantibodies in serum or FF (data not show).

Strong negative correlations of serum and FF fT4 levels with serum oestradiol (E2) were observed, but no such correlations were observed with FF E2 levels. The opposite correlation patterns were found between serum E2 levels andserum and FF TSH levels.
BMI had a statistically significant impact on ART outcome $(p \leq 0.001)$. Different aetiologies of infertility (male, female, both male and female, and unknown cause) did not have a statistically significant impact on ART outcome $(p=0.395)$.

\section{Discussion}

The present study verified the presence of THs and thyroid autoantibodies in the FF of women undergoing ART and assessed the impact of these factors on embryonic development and ART outcomes. We demonstrated the presence of TSH, T4, T3, fT4, fT3 and thyroid autoantibodies in FF, and estimated their impact on fertilization and embryo development during ART. Our study highlighted that the majority of patients have FF TH levels within the normal serum range $[15,16]$ We also observed a significant positive correlation between serum and FF TH levels, indicating that the majority of THs detected in FF seem to be derived from peripheral blood and enter follicles through theca interna cells. Moreover, we detected significantly higher concentrations of T3 in FF than in serum, whereas T4 concentrations were higher in serum than in FF, which is in line with the findings of previous studies [15, 17]. Our work also showedthat the T4/T3 ratio was much lower in FF than in blood, which supportsthe presence of an ovarian 5 '-monodeiodinase system in FF capable of generating T3 (ovary- generated T3) by outer ring deiodination of T4 [17]. We also detected thyroid autoantibodies in FF, but the levels were much lower than in serum. The results suggest that the blood-follicle barrier is a permselective barrier for thyroid autoantibodies.

The pivotal role of $\mathrm{THs}$ in several aspects of female reproduction have been well documented by several investigators. THs may impact folliculogenesis [19-21], ovarian steroidogenesis [22], and endometrial receptivity [23]. There is evidence that thyroid function is associated with pregnancy outcome, particularly in IVF. Despite treatment, women with hypothyroidism may have lower chances of pregnancy success after IVF [24]. SCH may also impact reproduction, and treatment of women with $\mathrm{SCH}$ has been shown to improve IVF outcomes $[25,26]$, including increasing the rates of implantation, clinical pregnancy, and delivery.

Because of the strong associations of $\mathrm{SCH}$ with subfertility, the definition of euthyroidism in subfertile women is currently a topic of debate. TSH is considered the most sensitive test for thyroid function, so currently, studies investigating the association between $\mathrm{SCH}$ and infertility are based on serum TSH levels. In the present study, we showed no difference in TSH levels in euthyroid women undergoing ART among different IVF outcome groups. Our results are in line with those recently reported by Karmon AE et al. [6-8]. In the group of euthyroid women undergoing infertility treatment with 
Table 1 Clinical and pretreatment parameters, follicular fluid and serum concentrations of hormones in 165 patients undergoing ovarian stimulation

\begin{tabular}{|c|c|c|c|}
\hline Variables & $\begin{array}{l}\text { Successful } \\
\text { Pregnancy } \\
(N=72)\end{array}$ & $\begin{array}{l}\text { Implantation } \\
\text { Failure } \\
(N=93)\end{array}$ & $P$ value \\
\hline \multicolumn{4}{|l|}{ Clinical and treatment parameters } \\
\hline Age (yrs) & $31(28,34)$ & $34(28,36)$ & NS \\
\hline $\mathrm{BMI}(\mathrm{kg} / \mathrm{m} 2)$ & $22.5(20.6,25.2)$ & $20.8(18.9,22.6)$ & $\leq 0.001$ \\
\hline Basal FSH & $3.63(1.95,6.01)$ & $4.22(1.79,7.11)$ & NS \\
\hline AMH (ng/ml) & $3.56(1.78,3.91)$ & $3.46(2.25,4.13)$ & NS \\
\hline Oocytes (total) & $13.5(8.8,16.8)$ & $10(7,14)$ & 0.007 \\
\hline $\begin{array}{l}\text { Oocyte (MII) } \\
\text { Fertilization rate,\% }\end{array}$ & $\begin{array}{l}10.5(5.5,15) \\
65.9 \%\end{array}$ & $\begin{array}{l}8(6,10) \\
56.6 \%\end{array}$ & $\begin{array}{l}0.002 \\
\leq 0.001\end{array}$ \\
\hline Etiology of infertility(\%) & & & 0.395 \\
\hline Female infertility & $75 \%$ & $77.4 \%$ & \\
\hline Both male and female infertility & $16.7 \%$ & $9.7 \%$ & \\
\hline Infertility of unknown cause & $8.3 \%$ & $12.9 \%$ & \\
\hline Cleavage rate, $\%$ & $98 \%$ & $99.5 \%$ & NS \\
\hline \multicolumn{4}{|l|}{ Serum (day HCG) hormone levels } \\
\hline TSH (mIU/l) & $1.86(1.27,3.08)$ & $1.95(1.54,2.95)$ & NS \\
\hline $\mathrm{T} 4(\mathrm{nmol} / \mathrm{l})$ & $121.9(104.8,140.8)$ & $114.1(98.6,130.6)$ & 0.026 \\
\hline $\mathrm{T} 3(\mathrm{nmol} / \mathrm{l})$ & $1.98(1.74,2.22)$ & $1.98(1.75,2.13)$ & NS \\
\hline fT4(pmol/l) & $19.0(17.7,21.8)$ & $18.6(17.0,20.1)$ & 0.026 \\
\hline fT3(pmol/l) & $4.75(4.25,4.93)$ & $4.5(4.08,4.8)$ & NS \\
\hline TPO Ab (IU/ml) & $15.1(9.17,23.22)$ & $15.5(8.94,17.32)$ & NS \\
\hline TG Ab (IU/ml) & $16.6(13.86,22.2)$ & $14.4(13.3,19.9)$ & NS \\
\hline $\mathrm{T} 4 / \mathrm{T3}$ & $62.5(55.7,66.2)$ & $59.4(53.4,64.9)$ & 0.029 \\
\hline \multicolumn{4}{|l|}{ Follicular fluid hormone levels } \\
\hline $\mathrm{TSH}(\mathrm{mIU} / \mathrm{l})$ & $2.12(1.41,3.57)$ & $2.41(2.03 .3 .23)$ & NS \\
\hline $\mathrm{T} 4(\mathrm{nmol} / \mathrm{l})$ & $112.3(93.7124 .5)$ & $102.6(88.6116 .8)$ & NS \\
\hline $\mathrm{T} 3(\mathrm{nmol} / \mathrm{l})$ & $2.07(1.88 .2 .22)$ & $1.98(1.75,2.13)$ & NS \\
\hline fT4(pmol/l) & $19.0(17.5,21.3)$ & $18.1(16.8,19.9)$ & 0.009 \\
\hline fT3(pmol/l) & $4.67(4.33,5.0)$ & $4.19(4.20,4.88)$ & NS \\
\hline TPO Ab (IU/ml) & $8.4(5.0,13.9)$ & $10.1(5.0,12.7)$ & NS \\
\hline TG Ab (IU/ml) & $17.5(13.98,24.38)$ & $17.6(14.9,20.3)$ & NS \\
\hline $\mathrm{T} 4 / \mathrm{T} 3$ & $52.6(46.4,57.3)$ & $50.0(43.7,53.1)$ & 0.004 \\
\hline
\end{tabular}

Note: Values are Mean $\pm S D$, median and interquartile range, or $\mathrm{n}(\%)$ as indicated NS nonsignificant, which means $P \geq 0.05$

$F F$ follicular fluid, $B M I$ body mass index, $A M H$ anti-Mullerian hormone

ART, the authors observed no significant differences in clinical pregnancy or delivery rates among euthyroid infertile women with different preconceptional TSH levels after IUI.

However, evidence is lacking to support the use of T4 or fT4 to categorize euthyroid infertile women undergoing IVF and to predict pregnancy outcomes. It is unknown whether distinctions can be made among $\mathrm{TH}$ values within the normal range of TSH and the chances of certain fertility outcomes. In the current study, the major differences between women achieving pregnancy and those who experienced implantation failure were in serum T4, fT4 levels and the T4/T3 ratio, This discrepancy among TSH,T4 and fT4 levels might be explained by the physiology: COS-induced hyperestrogenism directly reduces serum fT4 levels by stimulating thyroid binding globulin (TBG) production, whereas the increase in serum TSH levels is achieved by a negative feedback 


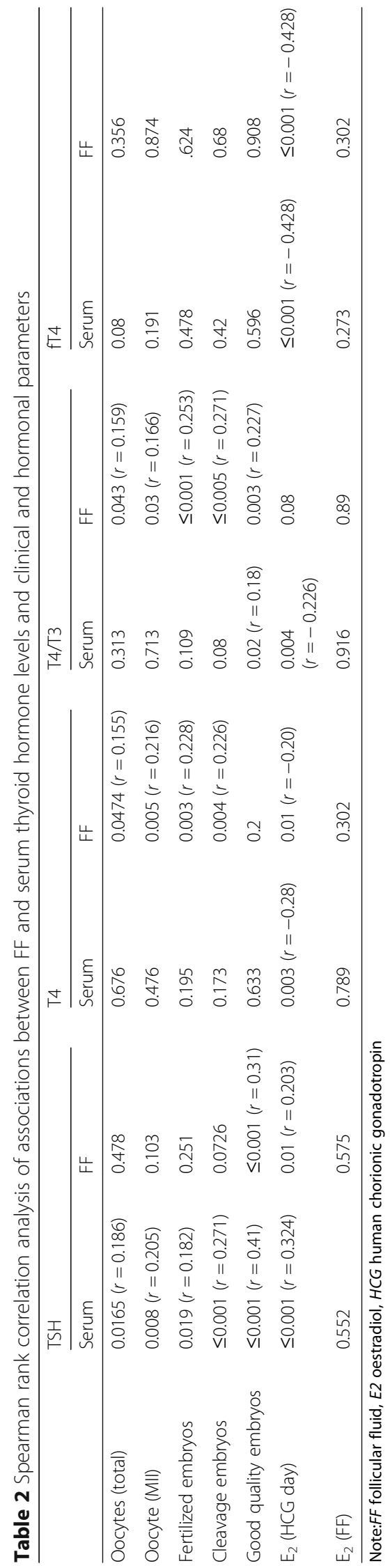


loop [27, 28]. Taken together, these data suggest that when there is a rapid increase in TBG leading to high variability in fT4 levels, the changes in TSH lags. Our study results show that the determination of fT4 levels and the T4/T3 ratio in serum on the day of OPU, together with TSH, maybe have greater prognostic value than TSH alone.

A growing body of literature indicates that the hormonal follicular milieu, which includes anti-Mullerian hormone and inhibin $\mathrm{B}$, is correlated with reproductive outcome after IVF [29]. However, few studies have examined the possible association between FF THs and IVF outcomes. Our results are the first to show a link among the FF T4/T3 ratio, embryonic developmental competence and successful pregnancy. Embryo quality is an important predictor of ART success. As expected,the successful pregnancy group had a significantly higher mean number of blastomeres, MII oocytes and retrieved oocytes than the implantation failure group. Significant correlations were found between the numbers of retrieved oocytes and fertilized oocytes and serum TSH levels and the FF T4/T3 ratio. Kamron's study advocates that thyroid function in subfertile women could indicate an insufficient capacity for basic reproductive functions such as oocyte quality, ovulation, fertilization and implantation [30]. Free TH supplementation $(50 \mathrm{ng} / \mathrm{ml}$ of T3 and T4) led to significant increases in blastocyst formation and hatching rates in bovine embryos [31], and in the expansion rate of the blastocoel cavity of cryopreserved bovine embryos. Although an exact mechanism cannot be assumed, it is noteworthy that thyroid dysfunction may impact IVF outcomes, possibly at the level of oocyte quality.

No statistically significant difference was found between groups in the levels of thyroid autoantibodies in serum and FF. There was no statistically significant correlation between the number of retrieved oocytes or fertilized oocytes and the levels of thyroid autoantibodies in serum and FF. These findings support the theory that thyroid autoantibodies in FF do not affect oocyte number, oocyte maturation, orquality or preimplantation embryos during ART [32, 33]. However, other studies which only focus on serum TAI have found a lower fertilization rate in the thyroid autoimmunity (TAI)positive group in the TAI-negative group(63 vs $72 \%$ [34] and 64.3 vs $74.6 \%$ [35]). One of the limitations of our study and other study included FF TAI to analysis is the relatively small number of TAI-positive patients. Our study included 165 (15 TAI positive) patients, while Medenica's study included 52 (26 TAI positive) patients [32]. In addition, a previous study showed that thyroid antibodies cancross-react with zona pellucida and granulosa cells due to molecular mimicry [36].

Our results revealed significant negative correlations between serum E2 and fT4 in serum and FF. Not surprisingly, we also found a significant positive correlation between serum E2 and serum TSH. which could be explained by the COS-specific changes in oestrogen levels. A previous study showed that COS could lead to hyperestrogenism, through a rise in TBG, subsequently leading to a decrease in fT4 [27]. Our results support the theory that the adaptation of maternal THmetabolism to hyperestrogenism during pregnancy may be important for embryo survival [30, 31]. Similarly, COS-specific changesmight put stress on hypothalamus-pituitary-thyroid axis in a very short time and manifest as gestational thyroid disease, which subsequently creates a suboptimal environment during the early phase of implantation, which may increase the risk for IVF failure.

The use of a population of infertile women undergoing ART has some limitations. First, our outcomes were limited to cycle parameters and clinical pregnancy. Therefore, no conclusions can be drawn on any other obstetric or fetal end points. Second, whether these findings are generalizable to women without known fertility problems is still under debate. Additionally, a strong association between TH levels and pregnancy rate could not be found.

In conclusion, thyroid autoantibodies and mostTHs present in FF are not generated in the FF, but rather enter from the blood. Thyroid autoantibodies do not directly impact oocytes and embryos during ART, but on the OPU day,the T4/T3 ratios in both serum and FF were significantly higher in the group of women who became pregnant than in those who did not conceive. Our results highlight the importance of the adaptation of THmetabolism during COS.

Moreover, one point of practical importance regarding our study results is the confirmation of a strong correlation between serum and FF TH levels,which suggests that the complicated determinations of FF $\mathrm{TH}$ levels may not be necessary because serum $\mathrm{TH}$ levels provide the same information. Further studies with more samples should be performed to confirm our findings and to elucidate the relationships among ovarian stimulation protocols, oocyte quality, clinical pregnancy rate and longitudinal changes of THs levels during COS.

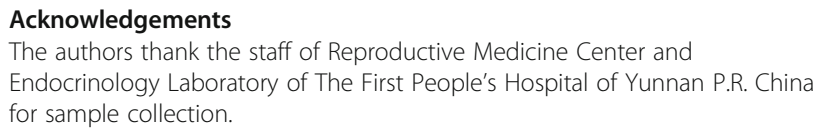

\section{Authors' contributions}

Patient selection: Y. C and L.N; sample collection and processing: L. N and L.Z; sample measurements: Y. D and H.D; data analysis and interpretation: $Y$. C and L.N; study design: H. S and Z.W; manuscript drafting: Y. C and H.S. All authors read and approved the final manuscript.

\section{Funding}

The present study was supported by Natural Science Foundation of China (Grant NO.81760143), Foundation for High-level Talents of Yunnan, China (Grant NO.L-201624) and Science and Technology Program of Yunnan, China (Grant NO.U0120170150). 


\section{Availability of data and materials}

The datasets used and/or analysed during the current study available fromthe corresponding author on reasonable request.

\section{Ethics approval and consent to participate}

All experiments were performed in strict accordance with the Ethics Committee at The First People's Hospital of Yunnan P.R. China. Informed consent was obtained from all subjects. The Institutional Committee of the First People's Hospital of Yunnan P.R. China approved the experimental protocols (registration number: 2017YY138).

\section{Consent for publication}

All co-authors have seen and approved the final version of the paper and have agreed to its submission for publication. All patients signed informed written consent forms.

\section{Competing interests}

The authors declare that they have no competing interests.

\begin{abstract}
Author details
${ }^{1}$ Medical School, Kunming University of Science and Technology, Kunming 650500, Yunnan Province, China. ${ }^{2}$ Department of Endocrinology, The Affiliated Hospital of Kunming University of Science and Technology, Kunming 650500, Yunnan Province, China. ${ }^{3}$ Reproductive Medicine Center, The Affiliated Hospital of Kunming University of Science and Technology, Kunming 650500, Yunnan Province, People's Republic of China.
\end{abstract}

\section{Received: 11 April 2019 Accepted: 4 October 2019}

\section{Published online: 07 November 2019}

\section{References}

1. Silva JF, Ocarino NM, SerakidesR. Thyroid hormones and female reproduction. BiolReprod. 2018;99(5):907-921. PMID: 29767691

2. Poppe K, Velkeniers B. Female infertility and the thyroid. Best Pract Res ClinEndocrinolMetab 2004;18(2):153-165. PMID: 15157833

3. Rao M, Zeng Z, Zhao S, Tang L. Effect of levothyroxine supplementation on pregnancy outcomes in women with subclinical hypothyroidism and thyroid autoimmuneity undergoing in vitro fertilization/intracytoplasmic sperm injection: an updated meta-analysis of randomized controlled trials. ReprodBiolEndocrinol. 2018;16(1):92. PMID: 30249251

4. Zhao T, Chen BM, Zhao XM, Shan ZY. Meta-analysis of ART outcomes in women with different preconception TSH levels. ReprodBiolEndocrinol. 2018;16(1):111. PMID: 30396353

5. Reh A, Grifo J, Danoff A. What is a normal thyroid-stimulating hormone (TSH) level? Effects of stricter TSH thresholds on pregnancy outcomes after in vitro fertilization. FertilSteril. 2010;94(7):2920-2922. PMID: 20655528

6. Karmon AE, Batsis M, Chavarro JE, Souter I. Preconceptional thyroidstimulating hormone levels and outcomes of intrauterine insemination among euthyroid infertile women. Fertil Steril. 2015;103(1):258-63.e1. PMID: 25439842

7. Unuane D, Velkeniers B, Bravenboer B, Drakopoulos P, Tournaye H, Parra J, De Brucker M. Impact of thyroid autoimmunity in euthyroid women on live birth rate after IUI. Hum Reprod 2017 Apr 1;32(4):915-922. PMID: 28333271

8. Repelaer van Driel-Delprat CC, van Dam EWCM, van de Ven PM, Homsma S, van der Kooij L, Vis E, Peeters RP, Schats R, Lambalk CB. Live birth rate after intrauterine insemination is not different between women with lower quartile versus higher quartile normal range thyroid stimulating hormone levels. Hum Reprod Open.;2019(1):hoz002. doi: https://doi.org/10.1093/ hropen/hoz002. eCollection 2019. PMID: 30895267

9. Da Broi MG, Giorgi VSI, Wang F, Keefe DL, Albertini D, Navarro PA. Influence of follicular fluid and cumulus cells on oocyte quality: clinical implications. J Assist Reprod Genet 2018 May;35(5):735-751. PMID: 29497954

10. Emori MM, Drapkin R. The hormonal composition of follicular fluid and its implications for ovarian cancer pathogenesis. ReprodBiolEndocrinol. 2014 Jul 6;12:60. PMID: 24997727

11. de los Santos MJ, García-Láez V, Beltrán-Torregrosa D, Horcajadas JA, Martínez-Conejero JA, Esteban FJ, Pellicer A, Labarta E. Hormonal and molecular characterization of follicular fluid, cumulus cells and oocytes from pre-ovulatory follicles in stimulated and unstimulated cycles. Hum Reprod 2012;27(6):1596-1605. PMID: 22451503
12. Cavallo IK, Dela Cruz C, Oliveira ML, Del Puerto HL, Dias JA, Lobach VN, Casalechi M, Camargos MG, Reis AM, Santos RA, Reis FM. Angiotensin-(1-7) in human follicular fluid correlates with oocyte maturation. Hum Reprod 2017 Jun 1;32(6):1318-1324. PMID: 28402544

13. Schweizer U, Steegborn C. New insights into the structure and mechanism of iodothyroninedeiodinases. J Mol Endocrinol. 2015;55(3):R37-R52. PMID: 26390881

14. Williams GR, Bassett JH. Deiodinases: the balance of thyroid hormone: local control of thyroid hormone action: role of type 2 deiodinase. J Endocrinol. 2011;209(3):261-272.PMID: 21292729.

15. Wakim AN, Polizotto SL, Buffo MJ, Marrero MA, Burholt DR. Thyroid hormones in human follicular fluid and thyroid hormone receptors in human granulosacells. FertilSteril. $1993 ; 59(6): 1187-1190$.PMID: 8495763.

16. De Silva M. Detection and measurement of thyroid stimulating hormone in human follicular fluid. J Reprod Med 1994;39(9):679-680. PMID: 7807478

17. Slebodziński AB.Ovarian iodide uptake and triiodothyronine generation in follicular fluid. The enigma of the thyroid ovary interaction. Domest Anim Endocrinol. 2005;29(1):97-103. Epub 2005 Apr 7.

18. Cedíková M, Babuška V, Rajdl D, Zech NH, Kališ V, Králičková M. Comparison of prolactin, free T3 and free T4 levels in the follicular fluid of infertile women and healthy fertile oocyte donors. Ceska Gynekol. 2012;77(5):471476. PMID: 23116354.

19. Verga Falzacappa C, Timperi E, Bucci B, Amendola D, Piergrossi P, D'Amico D, Santaguida MG, Centanni M, Misiti S. T (3) preserves ovarian granulosa cells from chemotherapy-induced apoptosis. J Endocrinol 2012 Nov;215(2): 281-289. PMID: 22911894

20. Zhang C, Guo L, Zhu B, Feng Y, Yu S, An N, Wang X. Effects of 3, 5, 3'triiodothyronine (t3) and follicle stimulating hormone on apoptosis and proliferation of rat ovarian granulosa cells. Chin J Physiol 2013;56(5):298305. PMID: 24032715

21. Fedail JS, Zheng K, Wei Q, Kong L, Shi F. Roles of thyroid hormones in follicular development in the ovary of neonatal and immature rats. Endocrine. 2014 Aug;46(3):594-604. PMID: 24254997

22. Cecconi S, Rucci N, Scaldaferri ML, Masciulli MP, Rossi G, Moretti C, D'Armiento M, Ulisse S. Thyroid hormone effects on mouse oocyte maturation and granulosa cell aromatase activity. Endocrinology. 1999 Apr; 140(4):1783-1788. PMID: 10098516

23. Aghajanova L, Stavreus-Evers A, Lindeberg M, Landgren BM, Sparre LS, Hovatta O. Thyroid-stimulating hormone receptor and thyroid hormone receptors are involved in human endometrial physiology. Fertil Steril. 2011 Jan;95(1):230-237, 237.e1-2. PMID: 20691434

24. Poppe K, Velkeniers B, Glinoer D. Thyroid disease and female reproduction. Clin Endocrinol 2007;66(3):309-321. PMID: 17302862

25. Abdel Rahman AH, Aly Abbassy H, Abbassy AA. Improved in vitro fertilization outcomes after treatment of subclinical hypothyroidism in infertile women [J]. A EndocrPract, 2010 ,16(5):792-797. PMID: 20350920

26. Kim CH, Ahn JW, Kang SP,et al. Effect of levothyroxine treatment on in vitro fertilization and pregnancy outcome in infertile women with subclinical hypothyroidism undergoing in vitro fertilization/ intracytoplasmic sperm injection [J]. FertilSteril, 2011;95(5):1650-1654. PMID: 21193190

27. Muller AF, Verhoeff A, Mantel MJ, De Jong FH, Berghout A. Decrease of free thyroxine levels after controlled ovarian hyperstimulation. J ClinEndocrinolMetab 2000;85(2):545-548. PMID: 10690853

28. Korevaar TIM, Medici M, Visser TJ, Peeters RP. Thyroid disease in pregnancy: new insights in diagnosis and clinical management. Nat Rev Endocrinol. 2017;13(10):610-22. 28776582.

29. Wunder DM, Guibourdenche J, Birkhäuser MH, Bersinger NA. Anti-Müllerian hormone and inhibin B as predictors of pregnancy after treatment by in vitro fertilization/intracytoplasmic sperm injection. Fertil Steril. 2008;90(6): 2203-10 Epub 2008 Feb 21.

30. Karmon AE,Cardozo ER, Souter I, Gold J, Petrozza JC, Styer AK. Donor TSH level is associated with clinical pregnancy among oocyte donation cycles. J Assist Reprod Genet 2016;33(4):489-494. PMID: 26847132

31. Ashkar FA, Semple E, Schmidt CH, St John E, Bartlewski PM, King WA. Thyroid hormone supplementation improves bovine embryo development in vitro. Hum Reprod 2010;25(2):334-344. PMID: 19920067

32. Medenica S, Garalejic E, Arsic B, Medjo B, Bojovic Jovic D, Abazovic D, Vukovic R, Zarkovic M. Follicular fluid thyroid autoantibodies, thyrotropin, free thyroxine levels and assisted reproductive technology outcome. PLoS One 2018;13(10):e0206652. PMID: 30372494 
33. Monteleone P, Parrini D, Faviana P, Carletti E, Casarosa E, Uccelli A, Cela V, Genazzani AR, Artini PG. Female infertility related to thyroid autoimmunity: the ovarian follicle hypothesis. Am J Reprodlmmunol. 2011;66(2):108-114. doi: https://doi.org/10.1111/j.1600-0897.2010.00961.x. Epub 2011 Jan 18. PMID: 21241400

34. Poppe $K$, Velkeniers $B$, Glinoer D. The role of thyroid autoimmunity in fertility and pregnancy. Nat ClinPractEndocrinolMetab. 2008;4(7):394-405. 18506157. https://doi.org/10.1038/ncpendmet0846.

35. Zhong YP, Ying Y, Wu HT, Zhou CQ, Xu YW, Wang Q, Li J, Shen XT, Li J. Relationship between antithyroid antibody and pregnancy outcome following in vitro fertilization and embryo transferlnt J Med Sci 2012;9(2): 121-125. doi: https://doi.org/10.7150/ijms.3467. Epub 2012 Jan 5. PMID: 22253557

36. Kelkar RL, Meherji PK, Kadam SS, Gupta SK, Nandedkar TD. Circulating autoantibodies against the zonapellucida and thyroid microsomal antigen in women with premature ovarian failure. J Reprodlmmunol 2005;66(1):53-67. PMID: 15949562

\section{Publisher's Note}

Springer Nature remains neutral with regard to jurisdictional claims in published maps and institutional affiliations.

Ready to submit your research? Choose BMC and benefit from:

- fast, convenient online submission

- thorough peer review by experienced researchers in your field

- rapid publication on acceptance

- support for research data, including large and complex data types

- gold Open Access which fosters wider collaboration and increased citations

- maximum visibility for your research: over $100 \mathrm{M}$ website views per year

At BMC, research is always in progress.

Learn more biomedcentral.com/submissions 